\title{
Note on the preservational nature of ornamentation in sphaeromorphs assignable to Tapajonites Sommer \& van Boekel, 1963 (Prasinophyta?)
}

\author{
ELŻBIETA TURNAU \\ Institute of Geological Sciences, Polish Academy of Sciences, Research Centre in Kraków, Senacka 1, 31-002 Kraków, Poland.
}

\begin{abstract}
Assemblages of Middle Devonian (Givetian) phytoplankton from the Holy Cross Mountains include sphaeromorphs possessing blister-like ornamentation typical of the genus Tapajonites Sommer \& van Boekel, 1963. Study of the sculptural elements under high magnification indicates the presence of patterns resembling impressions of pyrite crystals. It is suggested that ornamentation in Tapajonites, or at least in some sphaeromorphs assignable to that genus, is of a secondary nature. $J$. Micropalaeontol. 19(2): 159-162, December 2000.
\end{abstract}

\section{INTRODUCTION}

Abundant spores and phytoplankton have been recovered from the Middle Devonian (Givetian) shaly-marly Nieczulice Beds of the Holy Cross Mountains which outcrop between the villages of Skaly and Swietomarz (Fig. 1). Miospore stratigraphy and palynofacies of these deposits were discussed in Turnau \& Racki (1999), who also gave details of the sample locations.

The phytoplankton assemblages studied are dominated by prasinophytes, especially Leiosphaeridia and some thick-walled sphaeromorphs assigned to Hemiruptia. In some samples, sphaeromorphs displaying blister-like ornamentation are quite common. They were initially assigned to Tapajonites but later the author encountered forms with identical but randomly distributed ornamentation, which led to the conclusion that the blisters were preservational features. This was confirmed by the presence of wall structures visible under oil at $1000 \times$ magnification.

\section{SAMPLE, MACERATION AND REPOSITORY INFORMATION}

The material discussed below has been derived from the Nieczulice Beds cropping out at Skaly village (samples designated Sk) and in a trench at Pokrzywianka village (samples designated Po). The Nieczulice Beds are fine-grained, darkcoloured strata deposited in an intrashelf basin (see Turnau \& Racki,1999, figs 1C, 2A). They include interbedded sets of argillaceous shales, marls and marly limestones, with shaly lithologies being dominant. Abundant fauna occurs in places, but the assemblages (mostly brachiopods, crinoids, bivalves, styliolinids and ostracods) are less diverse in comparison with the underlying, fossiliferous Skaly Beds. There are sequences devoid of fauna, which may suggest recurrent low oxygen conditions. The palynological samples were grey or greenish clayey shales and marls derived from sequences or partings devoid of fauna. These samples were not enriched in marine

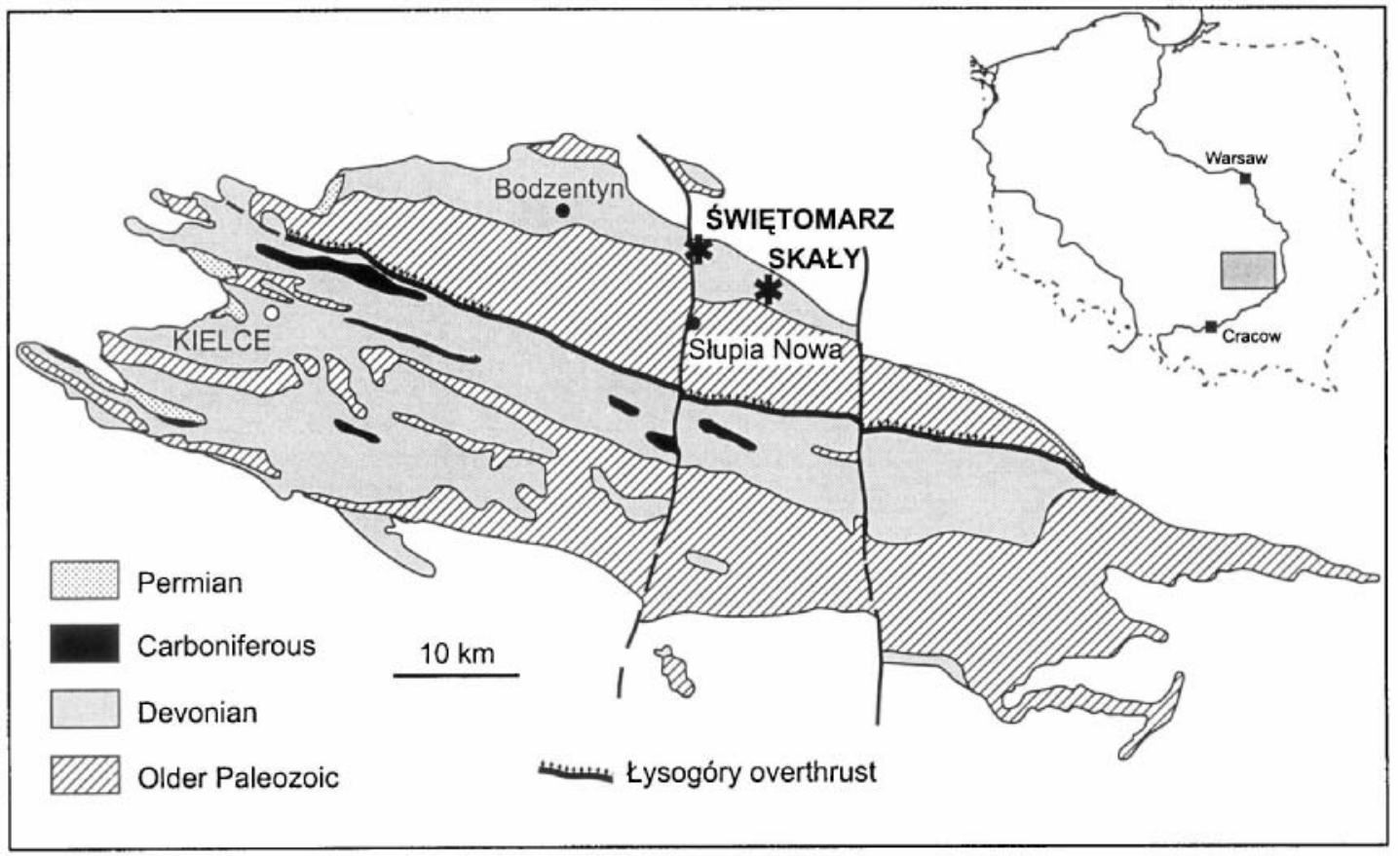

Fig. 1. Location of study area on a simplified geological map of the Holy Cross Mountains; inset, position of the Holy Cross Mountains within Poland. 

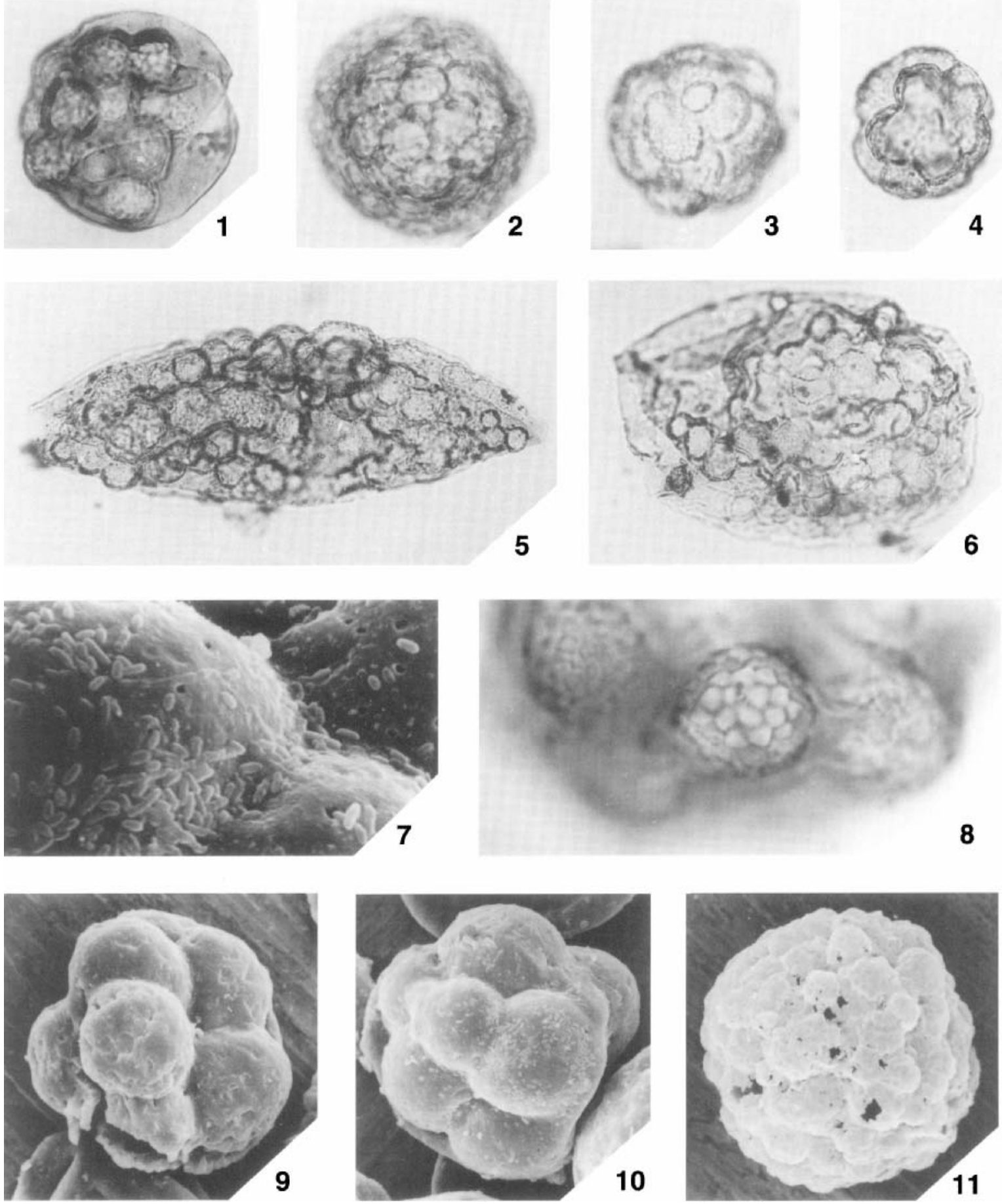

Explanation of Plate 1

Modification of wall membranes in Givetian sphaeromorphs from the Holy Cross Mountains. Magnification $\times 500$ except where otherwise stated. Fig. 1. Thick-walled sphaeromorph with one cluster of blister-like cavities; marks after pyrite appear as granulation. Sample SkIII/10, slide HCM9/ 60. Figs 2-4. Sphaeromorphs ornamented all over with blister-like cavities (a Tapajonites appearance): 2, sample SkIII/10, slide HCM9/60; 3, sample SS II $/ 1$, slide HCM $17 / 1 ; 4$, sample Sk/1, slide HCM 17/64, $\times 750$. Figs 5-6. Leiospheres with randomly distributed blister-like cavities. Marks after pyrite appear as distinct granulation: 5, sample Po/3, slide HCM17/34; 6, sample Po/3, slide HCM17/34. Fig. 7. SEM micrograph showing fragment of wall of specimen of Fig. 10 lacking external marks after pyrite, and displaying wall pores; bacteria on surface must be contamination. Magnification $\times 2500$. Sample SkIII/10. Fig. 8. Detail of blister-like ornamentation showing marks after pyrite on inner surface of cavity. Sample Po/ 3, slide HCM 17/34. Magnification $\times 1500$. Fig. 9. SEM micrograph of sphaeromorph showing wall broken by growth of pyrite framboids. Sample SkIII/10. Magnification $\times 680$. Figs 10, 11. SEM micrographs of sphaeromorphs ornamented with blister-like cavities of various sizes. Sample SkIII/ 10. Magnification $\times 700$ and $\times 850$ respectively. Sk and Po refer to Skaly and Pokrzywianka villages, respectively (see text). All material is deposited in the Institute of Geological Sciences, Polish Academy of Sciences, Krakow. 
organic matter, which would indicate deposition in anoxic conditions, but this may be due, at least in part, to outcrop weathering.

Palynomorphs were isolated from the rocks using standard palynological techniques. This includes $\mathrm{HCl}-\mathrm{HF}-\mathrm{HCl}$ acidation followed by heavy liquid separation and oxidation using $\mathrm{HNO}_{3}$. Residues are embedded in Cellosise and cemented to a microscope slide with Elvacite. All material is deposited in the Institute of Geological Sciences, Polish Academy of Sciences, in Kraków.

\section{DESCRIPTION OF SPECIMENS AND COMPARISON WITH TAPAJONITES}

Specimens bearing the blister-like ornamentation vary in size and appearance. The observed vesicle diameters are $40-200 \mu \mathrm{m}$, and the wall thickness is between $2 \mu \mathrm{m}$ and $8 \mu \mathrm{m}$. In some forms, the entire wall surface is covered by roughly equidimensional blisters ( $\mathrm{Pl}$. 1, figs 2-4, 9-11), or the ornamentation is confined to parts of the surface (Pl. 1, figs $1,5,6)$. The observed diameter of the blisters is $6-25 \mu \mathrm{m}$, but their size does not appear to be related to the vesicle size. Under $400 \times$ magnification, the blistercovered surface seems to be granulate. Observation under oil at $1000 \times$, with progressively deeper focusing shows that the blisters are cavities within the wall membrane. The margins of the cavities are scalloped and, at the highest and lowest focus, the membrane shows a pattern of angular, lighter fields measuring less than $1 \mu \mathrm{m}$ across (Pl. 1, fig. 8). As revealed by observation under SEM, this internal pattern may not show at the vesicle surface (pl. 1, fig. 10), or may be vaguely expressed by cracks in the vesicle wall (Pl. 1, fig. 9). Wall pores c. $0.3 \mu \mathrm{m}$ in diameter, are visible under SEM (Pl. 1, fig. 7).

The genus Tapajonites was erected by Sommer \& van Boekel (1963) who studied Middle Devonian phytoplankton from Brazil. Two species were originally assigned to the genus: $T$. roxoi Sommer \& van Boekel (designated as type species) and $T$. mosesil (Sommer). The latter species has been transferred to Maranhites by Brito (1967). The present paper does not apply to M. mosesii.

Sommer \& van Boekel (1963) describe the ornamentation of $T$. roxo i in the following way. 'Ornamentation, at the margin advancing clearly beyond the outline, consisting of humps rather regularly spaced, light yellow in colour; all over the surface, irregularly distributed, are numerous little discs about 10 micra in diameter, of intense yellow colour and a more orange hue.' The light colour of the humps and discs suggests that they may be hollow. In Sommer \& van Boekel (1963, pl. 1, figs 1,2), one can see that they are indeed lighter and of distinct granular texture.

Jux (1977) studied the wall structure in some tasmanitids from the Middle Devonian of Brazil, including specimens assignable to Tapajonites. Jux assigned his specimens to Tapajonites mosesii, but it is clear from the illustrations (Jux, 1997, pl. 4, figs 1-3) that, in these specimens, the distribution of protuberances on the wall surface is more like that in T. roxoi (the type species of Tapajonites), and unlike that in $T$. mosesii (now Maranhites mosesii (Sommer) Brito, 1967). It was demonstrated that the ornamentation elements in Tapajonites are cavities within the wall membrane of these fossils. They have scalloped margins (see Jux, 1977, pl. 4, fig. 4a) and are domed over the wall surface. Canals can be seen leading from the wall surface to the cavity. Jux suggested that the cavities might have acted as some form of hydrostatic device.

\section{DISCUSSION}

The appearance of different forms of blister-like structures simulating spore exine ornamentation has been described by Neves \& Sullivan (1964). These authors indicated the secondary nature of the structures and discussed their development, attributing their origin to the growth of pyrite crystals and aggregates within wall membranes of spores and phytoplankton. They distinguished three forms of cavities. Those described from the Holy Cross Mountains agree with the features of compound cribrate cavities of these authors.

Guy-Ohlson (1996, pl. 1, fig. 10) illustrated in a SEM micrograph a pattern appearing on the inner surface of a phycoma wall that is exactly like the pattern of angular fields described above and shown in Pl. 1, fig.8. Guy-Ohlson suggested that these marks were the imprints of pyrite cristals.

Neves \& Sullivan (1964) noted that exine deformation by pyrite growth occurred in certain morphological types of spores and their distribution was controlled by spore structural elements. The results of the present observations indicate that in phytoplankton, the described wall modification occurs primarily in prasinophytes, especially in sphaeromorphs. This is probably because these forms possess wall canals which allowed the initial penetration of bacteria, and the subsequent growth of pyrite framboids. The distribution pattern of the blisters has to be controlled, in most cases, by the distribution of the canals.

Pyrite deformation structures in palynomorphs are usually easily recognized as such, especially when occurring in spores. However, blisters distributed more or less regularly on the wall surface, occurring in sphaeromorphs which lack distinct morphological features, may be easily mistaken for sculpture. The original description and illustrations of Tapajonites roxo $i$ do not permit a complete understanding of the nature of the protuberances to be formed, and the Tapajonites specimens showing the internal wall structure (Jux, 1977) have been described from another locality. It is, therefore, difficult to decide whether the genus should be abandoned or retained. The Tapajonites-like forms described above are, however, definitely deformed sphaeromorphs, and so are some other forms described in the literature as Tapajonites. The external morphology and the wall structure in the Tapajonites mosesii described by Jux (1977, pp. 6-9, pl. 4, figs 1-4) suggest the preservational nature of the wall cavities. Specimens assigned to the discussed genus also occur in abundance in Middle-Upper Frasnian deposits of the Rheinisches Schiefergebirge in Germany, from where Amirie (1984) has illustrated specimens (op cit. pl. 11, figs 4-9) which appear identical to the forms described here. Tapajonites sp. I (Martin, 1984, pp. 33-34, pl. 7, fig. 9) may also be a deformed sphaeromorph.

\section{ACKNOWLEDGEMENTS}

The author thanks Dr Zbigniew Sawlowicz from the Institute of Geological Sciences of the Jagiellonian University, for discussion on pyrite mineralization, and Dr Bernard Owens from the 
Department of Geology, University of Sheffield for assistance with the improvement of the English version of the manuscript.

\section{Manuscript received February 2000 Manuscript accepted September 2000}

\section{REFERENCES}

Amirie, G. H. B. 1984. Phytoplankton aus dem Frasne des Bergischen Landes, Rheinisches Schiefergebirge. Geologisches Institut der Universitaet zu Koeln Sonderveroeffentlichungen, 49: 1-99.

Brito, I. M. 1967. Nôvo subgrupo de Acritarcha do Devoniano do Maranhão. Anais da Academia brasileira de Ciencias, 39: 163-166.

Guy-Ohlson, G. 1996. Chapter 7B. Prasinophycean algae. In Jansonius, J. \& McGregor, D. C. (Eds), Palynology: principles and applications. 181-189. American Association of Stratigraphic Palynologists Foundation, 1.
Jux, U. 1977. Über die Wandtstructuren sphaeromorpher Acritarchen: Tasmanites Newton, Tapajonites Sommer \& Van Boekel, Chuaria Walcott. Palaeontographica B, 160: 1-16.

Martin, F. 1984. Acritarches du Frasnien Superieur et du Famennien Inferieur du bord meridional du Bassin de Dinant (Ardenne belge). Bulletin Institut royal des Sciences naturelles de Belgique, 55 (7): 1-57.

Neves, R. \& Sullivan, H. J. 1964. Modification of spore exines associated with the presence of pyrite crystals. Micropaleontology, 10: 443-452.

Sommer, F. W. \& van Boekel, N. M. 1963. Some new Tasmanaceae from the Devonian of Pará. Anais da Academia brasileira de Ciências, 35: $61-65$.

Turnau, E. \& Racki, G. 1999. Givetian palynostratigraphy and palynofacies: new data from the Bodzentyn Syncline (Holy Cross Mountains, central Poland). Review of Palaeobotany and Palynology, 106: $237-271$. 